\title{
Chromosomal mapping and quantitative analysis of estrogen-related receptor alpha-1, estrogen receptors alpha and beta and progesterone receptor in the bovine mammary gland
}

\author{
E E Connor, D L Wood, T S Sonstegard, A F da Mota ${ }^{1}$, \\ G L Bennett ${ }^{2}$, J L Williams ${ }^{3}$ and A V Capuco \\ Bovine Functional Genomics Laboratory, USDA-ARS, Beltsville, Maryland 20705, USA \\ ${ }^{1}$ EMBRAPA-National Dairy Cattle Research Center, Juiz de Fora-MG, 36038-330, Brazil \\ ${ }^{2}$ Production Systems Research, US Meat Animal Research Center, Clay Center, Nebraska 68933, USA \\ ${ }^{3}$ Roslin Institute, Midlothian EH25 9PS, Scotland, UK \\ (Requests for offprints should be addressed to A V Capuco, Building 200, Room 14, BARC-East, Beltsville, MD 20705, USA; \\ Email: acapuco@anri.barc.usda.gov)
}

\begin{abstract}
Steroid receptors are key transcriptional regulators of mammary growth, development and lactation. Expression of estrogen receptors alpha $(\operatorname{ER} \alpha)$ and beta $(\operatorname{ER} \beta)$, progesterone receptor (PR), and estrogen-related receptor alpha-1 (ERR $\alpha)$ have been evaluated in bovine mammary gland. The ERR $\alpha$ is an orphan receptor that, in other species and tissues, appears to function in the regulation of estrogen-response genes including lactoferrin and medium chain acyl-CoA dehydrogenase and in mitochondrial biogenesis. Expression of $\mathrm{ER} \alpha, \mathrm{ER} \beta, \mathrm{PR}$ and $\mathrm{ERR} \alpha$ was characterized in mammary tissue obtained from multiple stages of bovine mammary gland development using quantitative real-time RT-PCR. Expression was evaluated in prepubertal heifers, primigravid cows, lactating non-pregnant cows, lactating pregnant cows and nonlactating pregnant cows ( $n=4$ to 9 animals/stage). In
\end{abstract}

addition, $\mathrm{ER} \alpha, \mathrm{ER} \beta, \mathrm{PR}$ and $\mathrm{ERR} \alpha$ were mapped to chromosomes 9, 10, 15 and 29 respectively, by linkage and radiation hybrid mapping. Results indicated that expression of ER $\alpha, \mathrm{PR}$ and ERR $\alpha$ was largely coordinately regulated and they were present in significant quantity during all physiological stages evaluated. In contrast, ER $\beta$ transcripts were present at a very low concentration during all stages. Furthermore, no ER $\beta$ protein could be detected in bovine mammary tissue by immunohistochemistry. The ER $\alpha$ and PR proteins were detected during all physiological states, including lactation. Our results demonstrate the presence of ER $\alpha, \mathrm{PR}$ and ERR $\alpha$ during all physiological stages, and suggest a functional role for ERR $\alpha$ and a relative lack of a role for ER $\beta$ in bovine mammary gland development and lactation.

Journal of Endocrinology (2005) 185, 593-603

\section{Introduction}

Ovarian steroids are important regulators of mammary growth, development and lactation. Their influence on mammogenesis in numerous species has long been appreciated. Ovariectomy of calves prevents mammary growth, which can be restored by estrogen administration (Wallace 1953). Studies in rodents have confirmed these observations and demonstrated that estrogens are required for growth and morphogenesis of mammary ducts. Classical endocrine ablation and hormone replacement studies in rats (Lyons 1958) and recent estrogen receptor (ER) knockout studies in mice (Bocchinfuso \& Korach 1997) indicated that estrogens are essential for the normal mammary ductal growth that occurs from birth to sexual maturity. In sexually mature animals, progesterone is necessary for the lobulo-alveolar development that occurs during pregnancy (Lyons 1958, Brisken et al. 1998). During lactogenesis, a reduction in circulating levels of progesterone is necessary for induction of copious milk secretion, because progesterone inhibits effective induction of $\alpha$-lactalbumin synthesis and initiation of stage II lactogenesis by lactogenic hormones (Turkington \& Hill 1969, Capuco \& Tucker 1980, Shamay et al. 1987). Although estrogen may enhance lactogenesis, it is generally thought to inhibit lactation by reducing milk secretion (Bruce \& Ramirez 1970) and possibly by increasing mammary regression (Capuco et al. 2003).

The varied effects of estrogens and progesterone on the mammary gland are typically mediated by specific steroid receptors (Athie et al. 1996). However, the action of steroid receptors involves extensive interaction among nuclear receptors, their various isoforms, co-regulator proteins, and other hormones and growth 
factors (Saunders 1998, Feldman et al. 1999, Yee \& Lee 2000, Conneely 2001, McDonnell \& Norris 2002, Tremblay \& Giguere 2002, Conneely et al. 2003). The estrogen receptor exists as two isoforms encoded by separate genes, the classical ER $\alpha$ (Jensen \& Jacobsen 1962, Greene et al. 1986) and the more recently cloned and characterized ER $\beta$ (Kuiper et al. 1996). Expression of both $\mathrm{ER}$ isoforms has been reported in mammary tissue of a variety of species. Progesterone receptor (PR) is encoded by a single gene, but exists as two isoforms, $\mathrm{A}$ and $\mathrm{B}$, that are the result of transcription initiation from two promoters (Kastner et al. 1990). We have previously described the presence of ER and PR in mammary tissue of Holstein calves and their co-localization in a subpopulation of epithelial cells (Capuco et al. 2002a) and in cows during the periparturient period (Capuco et al. 1982). Although we demonstrated the presence of $\mathrm{PR}$ in lactating bovine mammary gland by ligand binding methodology (Capuco et al. 1982), it is commonly stated that lactating tissue does not contain PR. A recent study has evaluated changes in $\mathrm{ER}$ and $\mathrm{PR}$ expression in the bovine mammary gland (Schams et al. 2003). Much remains to be learned about the regulation of ER and PR in the bovine gland, despite their importance to mammary gland function.

Estrogen-related receptor alpha-1 $(\operatorname{ERR} \alpha)$ is a member of the group III nuclear receptor superfamily with extensive sequence homology with the estrogen receptors (Giguere et al. 1988, Giguere 1999). The ERR $\alpha$ is classified as an orphan receptor, with no known endogenous ligand. However, the quantity and activity of ERR $\alpha$ can be regulated by estrogen and $\operatorname{ERR} \alpha$ may play a role in the regulation of estrogen responsive genes (Shigeta et al. 1997b, Bai \& Giguere 2003). Of particular impact on mammary gland biology, ERR $\alpha$ appears to play a role in the regulation of lactoferrin, medium-chain acyl-CoA dehydrogenase and thyroid hormone receptor alpha gene activation (Zhang \& Teng 2000, Giguere 2002). Expression of ERR $\alpha$ has been reported for a number of tissues in humans and rodents, and we have detected a significant quantity of transcripts in bovine mammary tissue (A V Capuco, unpublished data).

The objectives of this study were to characterize expression of $\mathrm{ER} \alpha, \mathrm{ER} \beta, \mathrm{PR}$ and $\mathrm{ERR} \alpha$ throughout development and in different functional states of the bovine mammary gland and to map these genes on the bovine genome. Preliminary data were previously reported by Connor et al. $(2003 a, b)$.

\section{Materials and Methods}

\section{Animals and tissue sampling}

Mammary tissues used in this study were obtained from Holstein cattle at various stages of development: (1) 3-month-old heifers, $n=4$, (2) primigravid cows, $n=9$, (3) lactating multiparous non-pregnant cows, $n=5$, (4) lactating multiparous pregnant cows, $n=5$ and (5) nonlactating cows, 25 days after cessation of milking and 35 days before expected parturition, $n=5$. Mammary tissue from primigravid cows was obtained by biopsy (Farr et al. 1996, Capuco et al. 2001) and remaining tissues were obtained at the time of slaughter at the Beltsville Agricultural Research Center (BARC) abattoir. Use of animals for these investigations was approved by the BARC Animal Care and Use Committee.

Portions of mammary tissues obtained by biopsy or at slaughter were frozen in liquid nitrogen and stored at $-80{ }^{\circ} \mathrm{C}$ until RNA extraction. Other portions of tissues were fixed overnight in $10 \%$ neutral buffered formalin at $4{ }^{\circ} \mathrm{C}$ and then stored in $70 \%$ ethanol until dehydration and embedding for immunohistochemistry (IHC).

\section{Immunohistochemistry}

After fixation, tissues were processed for IHC as described previously (Capuco et al. 2002a), except that tissue sections labeled with primary antibody were stained using the Picture-Plus kit (Zymed Laboratories, San Francisco, CA, USA) according to the manufacturer's recommended protocol.

Primary antibody for localization of ER $\alpha$ was mouse monoclonal antibody C-311 (Santa Cruz Biotechnology Inc., Santa Cruz, CA, USA), used at a concentration of $2 \mu \mathrm{g} / \mathrm{ml}$. The primary antibody used for localization of ER $\beta$ was rabbit polyclonal antibody PA1-311 (Affinity BioReagents, Golden, CO, USA), used at a concentration of $4 \mu \mathrm{g} / \mathrm{ml}$. The primary antibody for PR localization was mouse monoclonal antibody clone PR-AT4.14 (Research Diagnostics Products Inc., Flanders, NJ, USA), which recognizes both $\mathrm{A}$ and $\mathrm{B}$ forms of $\mathrm{PR}$ and was used at a concentration of $5 \mu \mathrm{g} / \mathrm{ml}$.

Tissue sections were photographed with a Spot digital camera (Diagnostic Instruments Inc., Sterling Heights, MI, USA) on a Zeiss Axioskop microscope (Carl Zeiss Inc., Thornwood, NY, USA). To obtain grayscale images with suitable contrast of diaminobenzidine staining, image files were filtered using the orthochromatic filter in Iridius 1.1 Actions for Photoshop (Iridius, Daventry, Northamptonshire, UK) using Photoshop 7.0 (Adobe Systems Incorporated, San Jose, CA, USA).

\section{$R N A$ preparation and real-time $R T-P C R$}

Total RNA was isolated using RNeasy isolation kits with on-column DNase digestion (Qiagen Inc., Valencia, CA, USA). The RNA quality was evaluated and concentration determined using the Agilent 2100 Bioanalyzer with RNA 6000 Nano LabChip kits (Agilent Technologies, Palo Alto, CA, USA).

Reverse transcription was performed using the iScript cDNA synthesis kit (Bio-Rad Laboratories, Hercules, CA, USA). Purified RNA was diluted to a concentration of $35 \mathrm{ng} / \mu \mathrm{l}$. Five-hundred and twenty-five nanograms RNA 
Table 1 Summary of gene targets evaluated by quantitative real-time RT-PCR

\begin{tabular}{|c|c|c|c|c|c|c|c|}
\hline & $\begin{array}{l}\text { Fragment } \\
\text { size } \\
\text { (bp) }\end{array}$ & Sense primer $\left(5^{\prime} \rightarrow 3^{\prime}\right)$ & Antisense priemr $\left(5^{\prime} \rightarrow 3^{\prime}\right)$ & $\begin{array}{l}\text { Annealing } \\
\text { temperature } \\
\left({ }^{\circ} \mathrm{C}\right)\end{array}$ & $\begin{array}{l}\text { PCR } \\
\text { efficiency } \\
(\%)\end{array}$ & $\begin{array}{l}\text { Correlation } \\
\text { coefficient } \\
(r)\end{array}$ & $\begin{array}{l}\text { Mean } \\
\text { CV } \\
(\%)\end{array}$ \\
\hline \multicolumn{8}{|l|}{ Gene } \\
\hline$E R \beta$ & 128 & ACCTGCTGAATGCTGTGAC & GTTACTGGCGTGCCTGAC & $54 \cdot 0$ & $95 \cdot 2$ & 0.999 & $0 \cdot 41$ \\
\hline PR & 116 & CAGTGGTCAAGTGGTCTAAATC & TCTCCATCCTAGTCCAAATACC & $54 \cdot 0$ & $91 \cdot 7$ & $1 \cdot 000$ & $1 \cdot 07$ \\
\hline$E R R \alpha$ & 144 & GCCTCCAACGAGTGTGAG & CCGCCGCTTGTACTTCTG & $54 \cdot 0$ & $91 \cdot 9$ & 0.998 & $0 \cdot 84$ \\
\hline
\end{tabular}

$\mathrm{CV}$, coefficient of variation.

were used per $20-\mu 1$ reaction volume. For each first strand synthesis reaction, a parallel control reaction was performed in the absence of reverse transcriptase enzyme. Incubation conditions were those suggested by the manufacturer: $25{ }^{\circ} \mathrm{C}$ for $5 \mathrm{~min}, 42{ }^{\circ} \mathrm{C}$ for $30 \mathrm{~min}, 85^{\circ} \mathrm{C}$ for $5 \mathrm{~min}$.

Following reverse transcription, $2 \mu \mathrm{l}$ cDNA reaction product were used per $25 \mu$ l of real-time PCR reaction employing SYBR green detection. Primers were designed using Beacon Designer 2.1 software (Bio-Rad Laboratories) based on bovine mRNA sequences available in GenBank (U64962 (ER $\alpha$ ), AF110402 (ER $\beta$ ), AJ557823 (PR)) or tentative consensus sequences in the Bos taurus Gene Index (http://www.tigr.org/; TC180604 $(\operatorname{ERR} \alpha))$. Primer sequences and annealing temperature used for each gene target are presented in Table 1. Real-time PCR was performed in the Bio-Rad iCycler using iQ SYBR Green Supermix (Bio-Rad Laboratories). PCR amplicons were cloned into pCR4-TOPO cloning vector (Invitrogen Corp., Carlsbad, CA, USA) and sequenced using a CEQ8000 automated sequencer and DTCS Quickstart Chemistry (Beckman Coulter, Fullerton, CA, USA). The nucleotide sequence of each gene target was confirmed against previously reported bovine sequences.

Standards were prepared from PCR amplicons purified using the QIAquick purification kit (Qiagen Inc.). Product concentrations were determined using the Agilent 2100 BioAnalyzer and DNA 500 kits (Agilent Technologies) and diluted to contain $1 \times 10^{2}$ to $1 \times 10^{8}$ molecules per $\mu 1$. The quantity of cDNA in unknown samples was calculated from the appropriate external standard curve run simultaneously with samples. Samples and standards were assayed in duplicate. Assay performance for each gene is reported in Table 1.

\section{Linkage and radiation hybrid mapping}

Primers designed for PCR amplification of genomic DNA were based on bovine sequences of $\operatorname{ER} \alpha, \operatorname{ER} \beta, \mathrm{PR}$ and ERR $\alpha$ available in GenBank and the Bos taurus Gene Index (accession numbers U64962, NM_174051, AJ557823, and TC196217 respectively). Primers were positioned within consecutive exons to PCR amplify the intervening intron and produce an amplicon $<5 \mathrm{~kb}$, based on human gene structure information available in the NCBI LocusLink Evidence Viewer (http://www. ncbi.nlm.nih.gov/LocusLink/). Nucleotide sequences of primers, conditions used for PCR, and the putative intron amplified are provided with each GenBank dbSTS database entry. Amplification products were visualized by agarose gel electrophoresis, purified, and sequenced to confirm amplification of the targeted region. PCR amplification was then performed using genomic DNA from sires of the USDA bovine reference population (Bishop et al. 1994) and products were sequenced to identify single nucleotide polymorphisms (SNP) to be used as markers for linkage mapping. SNP marker genotypes from progeny of informative sires were characterized by direct sequencing using the CEQ8000 or an ABI Prism 3700 DNA automated sequencer (Applied Biosystems, Foster City, CA, USA). Linkage analysis was performed using CRI-MAP v. $2 \cdot 4$ (Green et al. 1990). For physical mapping of ER $\beta$, the Roslin-Cambridge 3000-rad bovine/hamster radiation hybrid panel (Invitrogen Corp.) was used, as previously described (Connor et al. 2004).

\section{ERa and PR $m R N A$ sequencing}

Clones containing partial cDNAs for $\operatorname{ER} \alpha$ and PR were identified in two bovine cDNA libraries produced in our laboratory. The PR clone was obtained from a mammary gland library (Sonstegard et al. 2002) and the ER $\alpha$ clone was isolated from an intestinal library (Baumann et al. 2005). Plasmid DNA was purified and sequenced in one direction first using the primer 5'-TGAGCGGATAACA ATTTCACACAG-3' and DTCS Quickstart chemistry (Beckman Coulter). Gene-specific primers were then designed for sequencing of the entire clone inserts using sequence information obtained from previous reactions (primer walking).

\section{Statistical analyses}

RT-PCR data were analyzed using a one-way ANOVA. Bonferroni's multiple comparison test was used for 

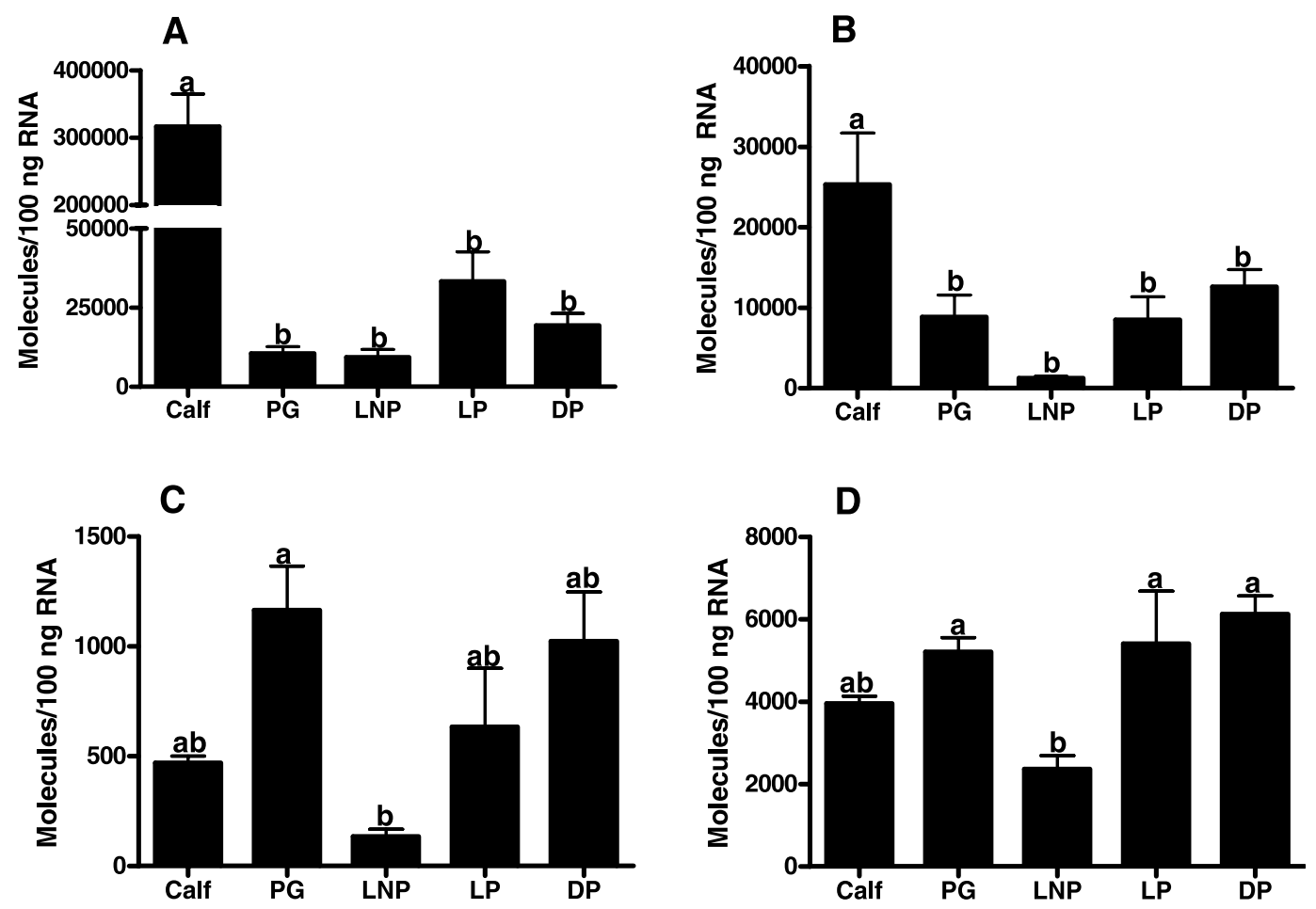

Figure 1 Expression of transcripts for estrogen receptor alpha (A), progesterone receptor $(B)$, estrogen receptor beta $(C)$, and estrogen-related receptor alpha (D) in bovine mammary gland. Calf, 3-month-old calves $(n=3)$; PG, primigravid cows 125-220 days of gestation $(n=9)$; LNP, lactating non-pregnant cows, 120 days of lactation $(n=5)$; LP, lactating pregnant cows, 240 days of lactation $(n=5)$; DP, non-lactating pregnant cows, 20 days after cessation of milking and 40 days before expected parturition $(n=5)$. Means without a common superscript differ $(P<0 \cdot 05)$. Note different concentrations on the y axes.

post ANOVA comparisons (Prism, version 4; GraphPad Software Inc., San Diego, CA, USA). Pearson correlation coefficient was determined using the mean transcript quantities for each of the five physiological stages (Prism, version 4).

\section{Results}

\section{Expression of steroid receptor transcripts}

The quantity of transcripts for ER $\alpha, E R \beta, P R$ and ERR $\alpha$ during mammary gland development and the lactation cycle are depicted in Fig. 1. For ER $\alpha$ and PR, transcripts were present in greatest abundance during the prepubertal period. Concentrations declined during first pregnancy, with generally greater concentrations found during late lactation and during the non-lactating period between successive pregnancies; we have referred to this period as the period of regenerative involution (Capuco et al. 2003). Following first conception, transcripts for ER $\alpha$ were at the greatest concentration in lactating, pregnant animals and transcripts for PR were greatest during regenerative involution. Expression of ERR $\alpha$ mRNA was moderate during all stages of development, with lowest concentrations occurring in early lactation. In contrast, ER $\beta$ transcripts were present at very low concentration throughout all stages evaluated (note different concentrations on the $y$ axes in Fig. 1). On average, concentrations for $\operatorname{ER} \beta$ were 8- to 190-fold lower than those for ER $\alpha, \operatorname{PR}$ and ERR $\alpha$. Patterns of expression appeared similar for ER $\alpha$ and PR, as did those for ER $\beta$ and ERR $\alpha$. Correlation coefficients were 0.90 for the relationship between transcript levels of $\mathrm{ER} \alpha$ and PR $(P<0.05)$ and 0.87 for the relationship between ER $\beta$ and $\operatorname{ERR} \alpha(P<0 \cdot 05)$.

\section{Steroid receptor protein expression}

Protein expression was evaluated by IHC (Figs 2 and 3). At all stages, ER $\alpha$ and PR were detected in nuclei of mammary epithelial cells. In the mammary parenchyma of the prepubertal heifer, ER and PR were mainly localized to nuclei of an intermediate layer within the epithelium. In the mature cow, expression of $\mathrm{ER} \alpha$ protein was quite uniformly expressed among epithelial cells of the lactating mammary gland, but expression was scattered among epithelial cells during pregnancy and during the period of 
regenerative involution. Progesterone receptor protein was expressed among scattered epithelial cells during pregnancy, lactation and regenerative involution. Expression of ER $\beta$ protein could not be detected in mammary tissue at any stage of development or function, although it was detectable in cells of the bovine anterior pituitary (Fig. 3).

\section{Mapping of steroid receptor genes}

To determine location in the cattle genome and to support identity of the bovine hormone receptor sequences according to human gene annotation, the $\operatorname{ER} \alpha, \operatorname{ER} \beta, \operatorname{PR}$ and ERR $\alpha$ genes were mapped to bovine chromosomes 9, 10,15 and 29 respectively on the USDA linkage map (Table 2). The GenBank accession numbers of each gene-associated sequence tagged site used to identify SNP for linkage analysis, as well as radiation hybrid mapping of $\mathrm{ER} \beta$, are provided in Table 2. The ER $\alpha$ gene was positioned near microsatellite marker BMS2295, at approximately $98.6 \mathrm{cM}$ on the USDA linkage map. The ER $\beta$ gene was positioned at approximately $79 \cdot 0 \mathrm{cM}$, near marker INRA037 on the linkage map and near marker INRA096 (distance $=0 \cdot 17 \mathrm{cR}$; LODS $=11 \cdot 31$ ) on the physical map. The PR gene was mapped near marker BMS2533 at approximately $13.9 \mathrm{cM}$ and $\operatorname{ERR} \alpha$ was positioned near marker $\mathrm{HH} 22$ at approximately $41 \cdot 6 \mathrm{cM}$. The nucleotide sequence data reported in this paper were submitted to GenBank and assigned accession numbers BV166870-166875, AY656812-656813.

\section{Discussion}

ER $\alpha$ was previously mapped to bovine chromosome 9 using somatic cell mapping (Womack et al. 1991). In the present study, ER $\alpha$ was positioned towards the telomeric end of bovine chromosome 9 at approximately $98.6 \mathrm{cM}$ on the linkage map. This is the first report of the chromosomal locations of ER $\beta, E R R \alpha$ and PR in cattle. For all four receptors, our findings agree with predicted locations based on bovine-human comparative maps (http:// locus.jouy.inra.fr/).

In the current work, two cDNA library clones containing partial codes for ER $\alpha$ and PR mRNA were sequenced and submitted to GenBank. For ER $\alpha$, over 3300 bp of the mRNA sequence not previously available for the bovine were obtained and correspond to the $3^{\prime} U T R$ of the transcript. Within this $3^{\prime} \mathrm{UTR}$, the bovine sequence shares 91\% identity with ovine $\operatorname{ER} \alpha$ (accession no. AY033393.1). For PR, approximately $1500 \mathrm{bp}$ of the bovine mRNA sequence were determined and they correspond to putative exons 1 through 8 of the PR gene. The bovine PR nucleotide sequence shares $97 \%$ identity with ovine and 92\% identity with canine and human mRNA sequences. It provides over $300 \mathrm{bp}$ of PR mRNA sequence not previously available for cattle.
Two major forms of ER exist, the ER $\alpha$ and $\operatorname{ER} \beta$ isoforms. We have demonstrated that the predominant isoform in mammary tissue of dairy cows is ER $\alpha$. The ER $\alpha$ transcript copy number was high throughout the mammary gland life cycle, with decreased expression during gestation, presumably due to high levels of endogenous estrogens. Additionally, the ER $\alpha$ protein was detectable by IHC during all stages examined. In contrast, transcripts for ER $\beta$ were present in exceedingly low concentration and the protein was undetectable by IHC throughout all physiological stages. Similarly, Schams et al. (2003) showed low expression levels of ER $\beta$ transcripts and low, but detectable, levels of protein expression by Western blot. These data suggest a relative lack of a role for ER $\beta$ in bovine mammary gland development and lactation.

ER $\alpha$ appears to mediate ductal growth and morphogenesis in mice (Bocchinfuso \& Korach 1997) rather than the ER $\beta$ isoform (Couse \& Korach 1999). The predominance of ER $\alpha$ prepubertally strongly suggests that the same is true in the bovine mammary gland. The concentration of ER $\alpha$ mRNA was greatest during the prepubertal period of mammary development, when estrogens are present at very low concentrations in the circulation, yet the mammary gland is hormonally responsive. We previously demonstrated that ER $\alpha$ is expressed in a subpopulation of epithelial cells and suggested that the estrogen signal is propagated in a paracrine fashion (Capuco et al. 2002a). Paracrine mediation of estrogeninduced mammary ductal growth similarly appears operative in mouse mammary gland. Tissue transplantation studies of epithelium and stroma between ER $\alpha$-null mice and wild-type mice demonstrated that estrogen responsiveness is mediated by paracrine factors, and that the ER $\alpha$ response differs with developmental stage. In neonatal mice, $\mathrm{ER} \alpha$ is expressed solely in the mammary stroma (Shyamala et al. 2002) and stromal ER $\alpha$ is necessary and sufficient to induce ductal growth (Cunha et al. 1997, Bocchinfuso et al. 2000). In adult mice ER $\alpha$ is expressed in a proportion of mammary epithelial and stromal cells (Shyamala et al. 2002), and ER $\alpha$ in epithelial cells appears important for tissue response to estrogens (Mueller et al. 2002). In both bovine and human mammary gland, paracrine mediation of estrogenic effects seemingly emanate from the limited number of ER $\alpha$-positive epithelial cells (Capuco et al. 2002a, Anderson \& Clarke 2004).

During pregnancy, lactation and regenerative involution, expression of ER $\alpha$ appears limited to mammary epithelial cells. The presence of ER $\alpha$ throughout phases of mammary gland development suggests that the potential for responsiveness to estrogenic stimuli exists throughout the life span of the dairy cow.

As with $\mathrm{ER} \alpha$, PR was present in bovine mammary glands during all physiological stages examined. Its expression is limited to mammary epithelial cells and it 
(A)

ER-alpha
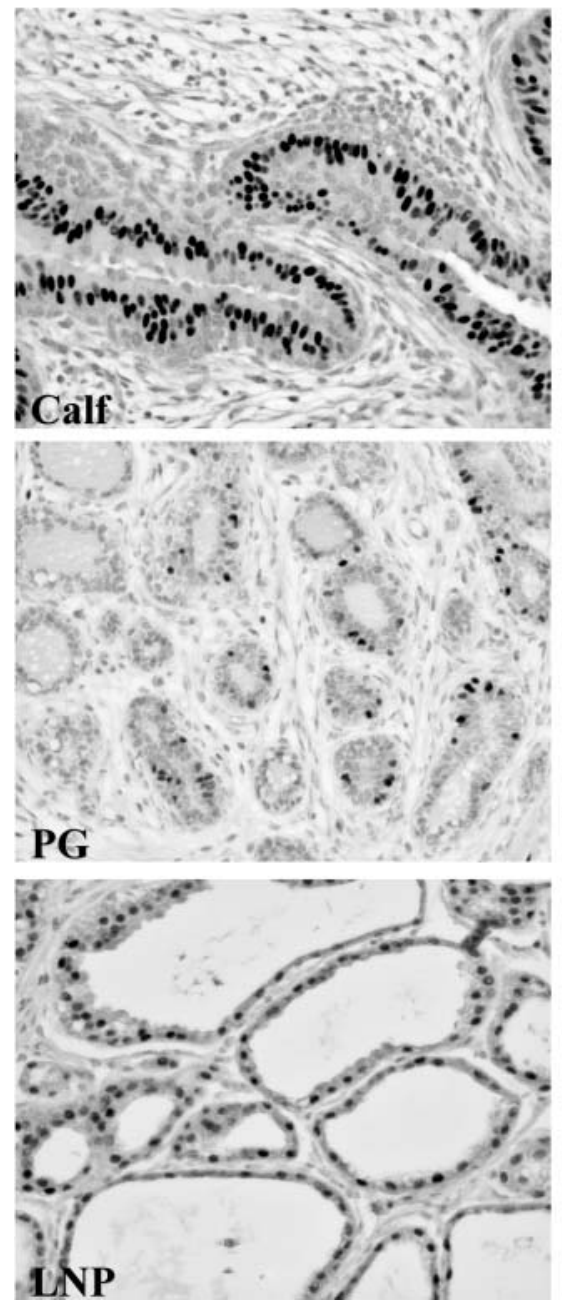

PR, A\&B
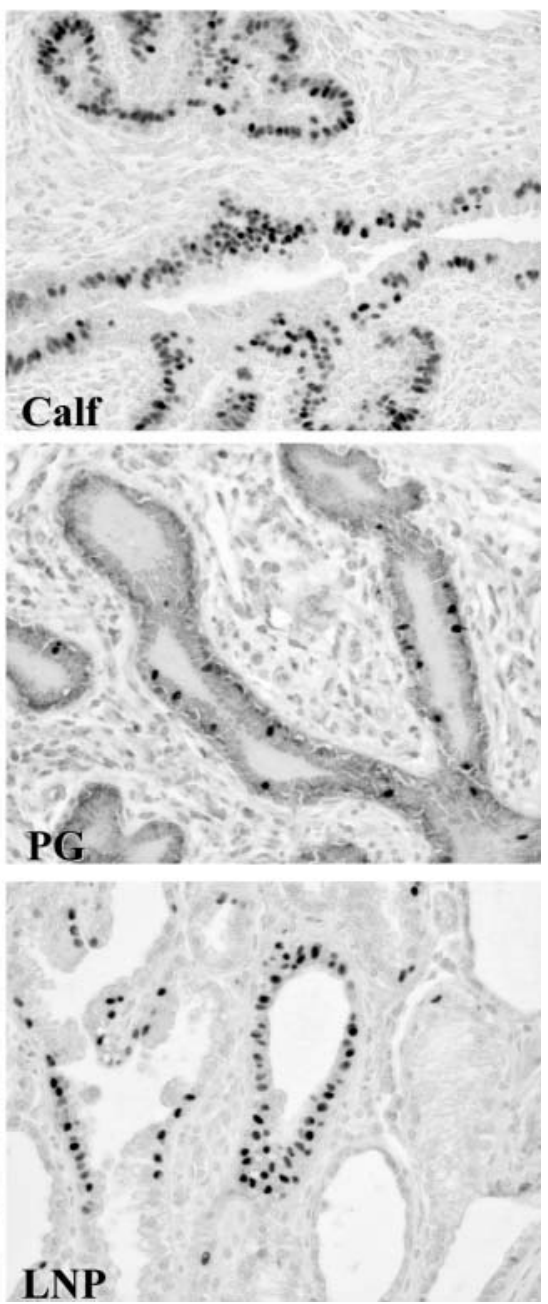

Figure 2 (A).

co-localizes with ER $\alpha$ in cow and human (Press \& Greene 1988, Anderson et al. 1998, Bartow 1998, Capuco et al. $2002 a$ ). The primary role of progesterone during mammary development is promotion of lobulo-alveolar development mediated by the PR (Lyons 1958, Nandi 1958, Smith et al. 1987, Shyamala 1999). Receptor knockout studies showed that PR in mammary epithelium is essential for ductal branching and lobulo-alveolar development, but not for mammary ductal elongation (Lydon et al. 1995). Steroid receptor knockout studies, antiestrogen implantation studies (Silberstein et al. 1994) and in vitro studies (Haslam \& Levely 1985, Woodward et al. 1998) suggest that ovarian steroids act directly at the level of the mammary gland. As with estrogen, the effects of progesterone on mammary development appear to involve paracrine mediators (Brisken et al. 1998).
Progesterone plays an important role as an inhibitor of the final stage of lactogenesis (Kuhn 1969, Turkington \& Hill 1969), yet it does not inhibit milk secretion during an established lactation (Herrenkohl 1974). In mature cows, these effects may be mediated by PR or interactions with other receptors, such as the glucocorticoid receptor (Capuco \& Tucker 1980). Assuming that PR serves as mediator, the lack of progesterone inhibition of milk secretion during lactation in rodents may be explained by the absence of the receptor during lactation, whereas its effectiveness as an inhibitor of lactogenesis is consistent with the presence of PR during pregnancy (Haslam \& Shyamala 1979). However, we previously demonstrated that PR is expressed in bovine mammary tissue both preand post-partum and attributed progesterone's ability to inhibit lactogenesis, but not an established lactation, to the 
(B)

\section{PR, A\&B}

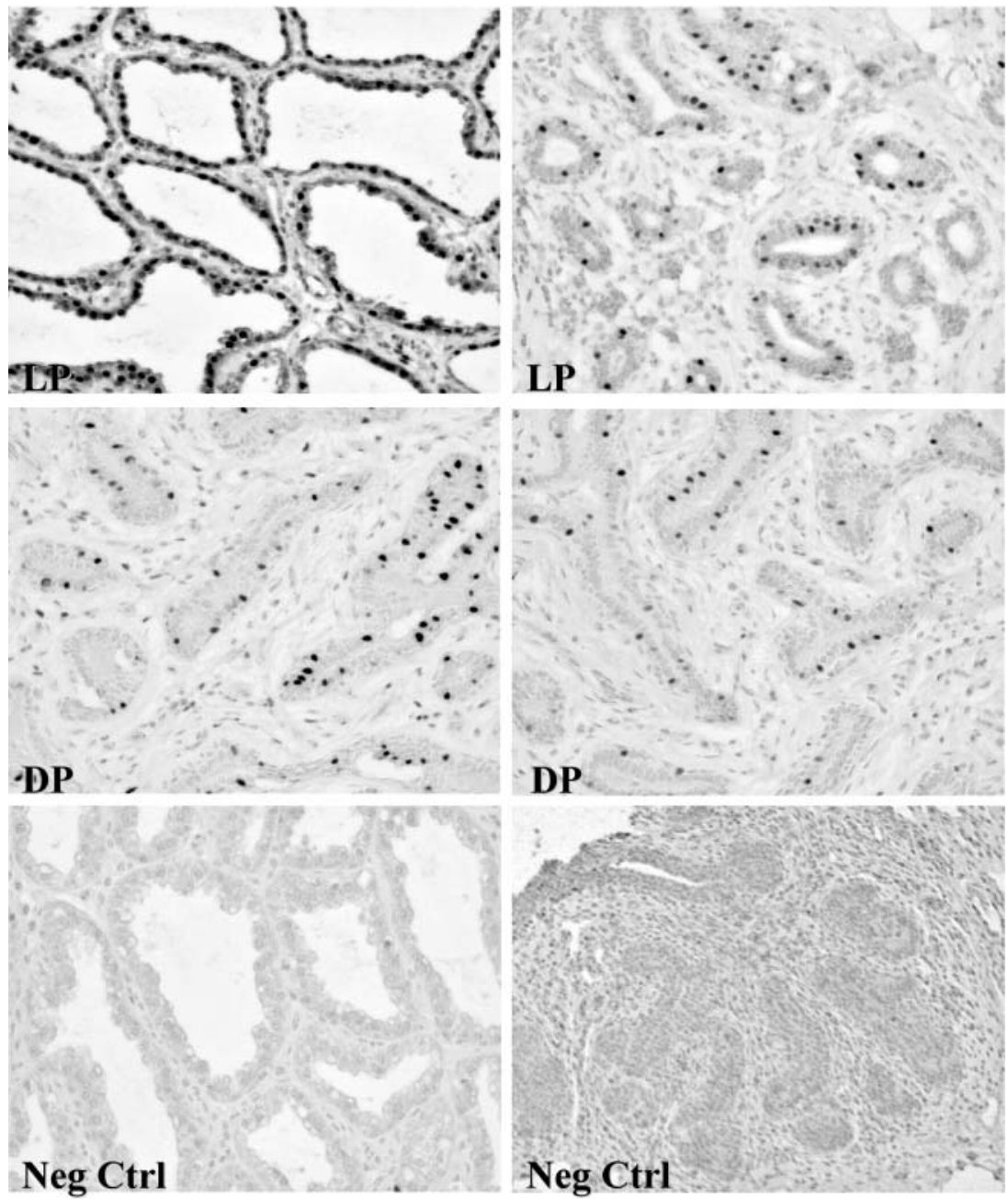

Figure 2 (B).

Figure 2 Immunohistochemical localization of estrogen receptor alpha and progesterone receptor $(\mathrm{PR}, \mathrm{A} \& \mathrm{~B})$ in bovine mammary gland. Representative micrographs are shown for (A) mammary glands of 3-month-old calves (calf), primigravid cows 150 days of gestation (PG), and lactating non-pregnant cows, 120 days of lactation (LNP) and (B) lactating pregnant cows, 240 days of lactation (LP) and non-lactating pregnant cows, 20 days after cessation of milking and 40 days before expected parturition (DP; dry pregnant). Negative control slides were incubated with non-immune serum or affinity purified immunoglobulins and showed no staining. Representative negative controls (Neg Ctrl) are shown.

observed decline in PR quantity and a shift in expression of PR isoforms (Capuco et al. 1982). Expression of PR in lactating tissues has been confirmed, and PR isoforms have been shown to be differentially expressed in mammary tissue of pregnant versus lactating cows (Schams et al. 2003). It is clear that expression of PR is not precluded by the lactational state. Even in mice, PR was expressed in lactating tissue when animals were concurrently pregnant (Capuco et al. 2002b). The present study suggests that expression of $\mathrm{PR}$ mRNA and immunoreactive protein during lactation is enhanced by concomitant pregnancy $(P<0 \cdot 1)$.

We speculate that the greater expression of $\mathrm{PR}$ during lactation in cows compared with rodents may be due to differences in ER $\beta$ expression between these species. Expression of PR is induced by activated ER $\alpha$ (Shyamala \& Ferenczy 1982, Shyamala et al. 1990). However, in rodents $\mathrm{ER} \alpha$ does not induce $\mathrm{PR}$ during lactation 


\section{ER-beta}
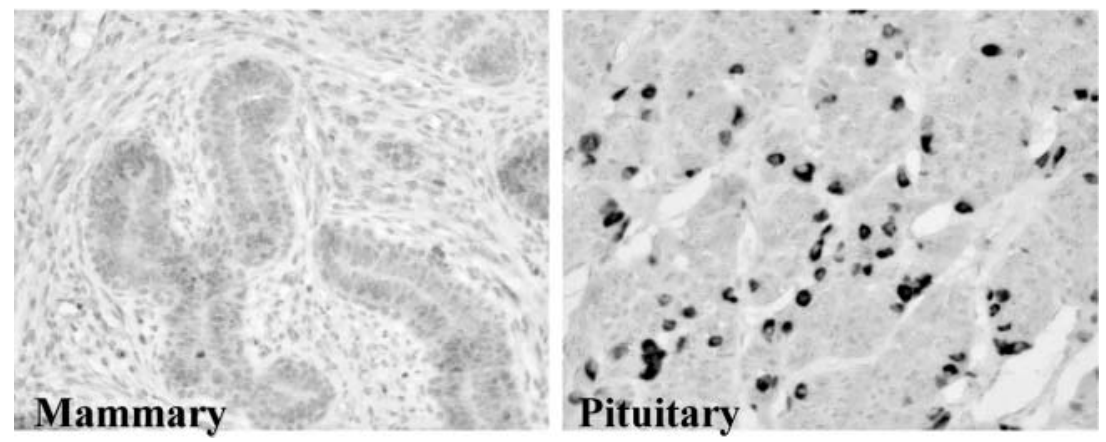

Figure 3 Immunohistochemical localization of estrogen receptor beta in mammary gland and anterior pituitary. The mammary gland was devoid of staining for estrogen receptor beta, whereas the pituitary demonstrated positive staining. Tissue sections from the mammary gland of a prepubertal (3-month-old) heifer and from the anterior pituitary of a multiparous nonlactating, nonpregnant cow are depicted.

(Shyamala \& Ferenczy 1982), and recent data suggest that this is due to inhibition by ER $\beta$ (Saji et al. 2001). An ER $\beta$ variant with a 54-bp insert between exons 5 and 6 has been reported for rat and referred to as ER $\beta 2$ or ER $\beta$ ins (Petersen et al. 1998, Saji et al. 2001). The ERßins co-localizes with $\operatorname{ER} \alpha$ and is in greater abundance than ER $\alpha$ during lactation (Saji et al. 2001). The increased ratio of ER $\beta$ ins to ER $\alpha$ during lactation has been hypothesized to permit ER $\beta$ ins to act as a dominant repressor of ER $\alpha$ and to repress expression of PR during lactation (Saji et al. 2001). Primers used in the present study amplified a region in the $3^{\prime}$ end of exon 8 and would not have distinguished between these variants. Limited expression of ER $\beta$ in the bovine mammary gland may preclude repression of ER $\alpha$ activity by $\mathrm{ER} \beta$ or its variants, resulting in PR expression in the lactating bovine mammary gland.
Based upon sequence homology to ERs, ERR $\alpha$ was the first orphan nuclear receptor to be identified and cloned (Giguere et al. 1988). Subsequently, related members (ERR $\beta$ and ERR $\gamma$ ) were cloned and studied to a limited extent (Giguere 2002). The ERRs do not bind natural estrogens and activate transcription constitutively (Giguere 2002). ERR $\alpha$ is regulated by estrogens and can regulate estrogen responsive genes (Shigeta et al. 1997a, Bai \& Giguere 2003), acting as an activator or inhibitor of gene expression depending upon numerous interactions (Vanacker et al. 1999, Giguere 2002, Kraus et al. 2002, Tremblay \& Giguere 2002). Although ER $\beta$ was consistently expressed at very low levels in bovine mammary gland, it is noteworthy that the expression of $\operatorname{ERR} \alpha$ and $\operatorname{ER} \beta$ was correlated.

The effects of ERR $\alpha$ on the mammary gland may include roles in cell differentiation and disease resistance.

Table 2 Summary of linkage mapping of bovine steroid receptors estrogen receptor alpha (ER $\alpha$ ), estrogen receptor beta (ER $\beta$ ), progesterone receptor (PR), and estrogen-related receptor alpha (ERR $\alpha)$

\begin{tabular}{|c|c|c|c|c|c|c|}
\hline & Accession no. & SNP* & Chromosome & $\begin{array}{l}\text { Nearest } \\
\text { marker }\end{array}$ & 2-pt LOD & $\begin{array}{l}\text { Recombination } \\
\text { fraction }\end{array}$ \\
\hline \multicolumn{7}{|l|}{ Locus } \\
\hline $\mathrm{ER} \alpha$ & BV166870 & A/G@ 169 & 9 & BMS2295 & $4 \cdot 27$ & $0 \cdot 05$ \\
\hline$E R \beta$ & BV166872 & & & & & \\
\hline \multirow[t]{5}{*}{ PR } & BV166874 & G/T@33 & 15 & BMS2533 & $20 \cdot 70$ & $0 \cdot 11$ \\
\hline & & A/G@ 89 & & & & \\
\hline & & AT indel @121 & & & & \\
\hline & & A/T@ 154 & & & & \\
\hline & BV166875 & & & & & \\
\hline $\mathrm{ERR} \alpha$ & BV166873 & C/T@129 & 29 & $\mathrm{HH} 22$ & $3 \cdot 61$ & $0 \cdot 12$ \\
\hline
\end{tabular}

${ }^{*}$ Type and nucleotides position of SNP in the dbSTS reference sequence used for linkage mapping. 
In addition to development within the mammary gland, there are changes in the number and differentiation status of the epithelial cells with each lactation cycle. ERR $\alpha$ is necessary for mitochondrial biogenesis (Vega et al. 2000, Puigserver \& Spiegelman 2003, Mootha et al. 2004), appears to play an important role in energy metabolism (Sladek et al. 1997, Vega \& Kelly 1997, Luo et al. 2003, Schreiber et al. 2003), and can impact thyroid hormone regulation of energy metabolism (Giguere 2002). A potential role for ERR $\alpha$ in facilitating the rapid mammary mitochondrial biogenesis, cell differentiation and energy partitioning among body tissues remains to be evaluated. It has been established that the gene for lactoferrin, a protein secreted into milk as well as secretions of the nonlactating gland, contains ER response elements and is, at least partially, regulated by ERR $\alpha$ (Liu et al. 1993, Yang et al. 1996, Zhang \& Teng 2000, 2001). Lactoferrin exhibits iron-binding capacity and bactericidal activity and aids in maintaining mammary gland health through its nonspecific immune functions.

The relationship between these nuclear receptors and dairy production traits warrants further attention. A quantitative trait locus (QTL) for milk somatic cell score (neutrophil concentration of milk, serves as an index of mastitis) was recently identified on bovine chromosome 29 at approximately $50 \mathrm{cM}$ (Ashwell et al. 2004). Thus, ERR $\alpha$ is a positional candidate gene influencing somatic cell score based on its role in the regulation of lactoferrin. Despite lack of evidence for a role of ER $\beta$ in bovine mammary gland development and lactation, ER $\beta$ may have a significant impact on dairy production through effects on ovarian function. A putative QTL for ovulation rate has been identified on bovine chromosome 10 with a peak at approximately 75 cM (Arias \& Kirkpatrick 2004), suggesting $\operatorname{ER} \beta$ as a positional candidate gene contributing to this trait. ER $\beta$ knockout mice exhibit decreased ovulation rate and reduced fertility (Krege et al. 1998), further implicating $\operatorname{ER} \beta$ as a candidate gene controlling fertility of dairy cattle. The relationships between ER $\beta$ and ovulation, ERR $\alpha$ and mastitis, and ERR $\alpha$ and mammary gland biology in dairy cattle are worthy of further investigation.

In conclusion, our results demonstrate the presence of ER $\alpha, P R$ and ERR $\alpha$ during all physiological stages of the mammary gland and suggest a functional role for these nuclear receptors throughout the life cycle of the dairy cow. Very low concentrations of $\operatorname{ER} \beta$ suggest a relative lack of a role for this transcription factor in bovine mammary gland development and lactation. Additional research pertaining to the spatial, temporal and functional attributes of ERR $\alpha$ expression in the bovine mammary gland is warranted.

\section{Funding}

Funding for this research was obtained from the United States Department of Agriculture, Agricultural
Research Service (CRIS \#1265-31000-086-00D). Radiation hybrid mapping was supported by the European Commission (Project QLRI-CT-2002-02744). Mention of a trade name or proprietary product does not constitute a guarantee or warranty by the USDA and does not imply approval to the exclusion of others not mentioned. No conflict of interest exists that would prejudice the impartiality of this research report.

\section{References}

Anderson E \& Clarke RB 2004 Steroid receptors and cell cycle in normal mammary epithelium. Journal of Mammary Gland Biology and Neoplasia 9 3-13.

Anderson E, Clarke RB \& Howell A 1998 Estrogen responsiveness and control of normal human breast proliferation. Journal of Mammary Gland Biology and Neoplasia 3 23-35.

Arias J \& Kirkpatrick B 2004 Mapping of bovine ovulation rate QTL: an analytical approach for three generation pedigrees. Animal Genetics 35 7-13.

Ashwell MS, Heyen DW, Sonstegard TS, Van Tassell CP, Da Y, VanRaden PM, Ron M, Weller JI \& Lewin HA 2004 Detection of quantitative trait loci affecting milk production, health, and reproductive traits in Holstein cattle. Journal of Dairy Science $\mathbf{8 7}$ 468-475.

Athie F, Bachman KC, Head HH, Hayen MJ \& Wilcox CJ 1996 Estrogen administered at final milk removal accelerates involution of bovine mammary gland. Journal of Dairy Science 79 220-226.

Bai Y \& Giguere V 2003 Isoform-selective interactions between estrogen receptors and steroid receptor coactivators promoted by estradiol and ErbB-2 signaling in living cells. Molecular Endocrinology 17 589-599.

Bartow SA 1998 Use of the autopsy to study ontogeny and expression of the estrogen receptor gene in human breast. Journal of Mammary Gland Biology and Neoplasia 3 37-48.

Baumann RG, Baldwin RL, Van Tassell CP, Matukumalli LK \& Sonstegard TS 2005 Characterization of a normalized cDNA library from bovine intestinal muscle and epithelial tissues. Animal Biotechnology 16 1-13.

Bishop MD, Kappes SM, Keele JW, Stone RT, Sunden SL, Hawkins GA, Toldo SS, Fries R, Grosz MD, Yoo J et al. 1994 A genetic linkage map for cattle. Genetics 136 619-639.

Bocchinfuso WP \& Korach KS 1997 Mammary gland development and tumorigenesis in estrogen receptor knockout mice. Journal of Mammary Gland Biology and Neoplasia 2 323-334.

Bocchinfuso WP, Lindzey JK, Hewitt SC, Clark JA, Myers PH, Cooper R \& Korach KS 2000 Induction of mammary gland development in estrogen receptor-alpha knockout mice. Endocrinology 141 2982-2994.

Brisken C, Park S, Vass T, Lydon JP, O'Malley BW \& Weinberg RA 1998 A paracrine role for the epithelial progesterone receptor in mammary gland development. PNAS 95 5076-5081.

Bruce JO \& Ramirez VD 1970 Site of action of the inhibitory effect of estrogen upon lactation. Neuroendocrinology 6 19-29.

Capuco AV \& Tucker HA 1980 Progesterone inhibition of glucocorticoid binding to mammary tissue from lactating and nonlactating cows. Proceedings of the Society for Experimental Biology and Medicine 164 386-393.

Capuco AV, Feldhoff PA, Akers RM, Wittliff JL \& Tucker HA 1982 Progestin binding in mammary tissue of prepartum, nonlactating and postpartum, lactating cows. Steroids 40 503-517.

Capuco AV, Wood DL, Elsasser TH, Kahl S, Erdman RA, Van Tassell CP, Lefcourt A \& Piperova LS 2001 Effect of somatotropin on thyroid hormones and cytokines in lactating dairy cows during ad libitum and restricted feed intake. Journal of Dairy Science $\mathbf{8 4}$ 2430-2439. 
Capuco AV, Ellis S, Wood DL, Akers RM \& Garrett W 2002a Postnatal mammary ductal growth: three-dimensional imaging of cell proliferation, effects of estrogen treatment and expression of steroid receptors in prepubertal calves. Tissue and Cell 34 9-20.

Capuco AV, Li M, Long E, Ren S, Hruska KS, Schorr K \& Furth PA $2002 b$ Concurrent pregnancy retards mammary involution: effects on apoptosis and proliferation of the mammary epithelium after forced weaning of mice. Biology of Reproduction 66 1471-1476.

Capuco AV, Ellis SE, Hale SA, Long E, Erdman RA, Zhao X \& Paape MJ 2003 Lactation persistency: insights from mammary cell proliferation studies. Journal of Animal Science 81 (Suppl 3) 18-31.

Conneely OM 2001 Perspective: female steroid hormone action. Endocrinology 142 2194-2199.

Conneely OM, Jericevic BM \& Lydon JP 2003 Progesterone receptors in mammary gland development and tumorigenesis. Journal of Mammary Gland Biology and Neoplasia 8 205-214.

Connor EE, Capuco AV, Sonstegard TS, Mota AF, Wood DL, Garrett W, Bennett GL \& Williams J 2003a Quantitative analysis of estrogen-related receptor alpha, estrogen receptor alpha and estrogen receptor beta mRNAs throughout bovine mammary gland development. Journal of Dairy Science 86 (Suppl. 1) 118.

Connor EE, Capuco AV, Wood DL, Sonstegard TS \& Mota AF $2003 b$ Ontogenetic regulation of progesterone receptor (PR) expression in bovine mammary gland. Journal of Dairy Science $\mathbf{8 6}$ (Suppl. 1) 302.

Connor EE, Sonstegard TS, Keele JW, Bennett GL, Williams JL, Papworth R, Van Tassell CP \& Ashwell MS 2004 Physical and linkage mapping of mammary-derived expressed sequence tags in cattle. Genomics 83 148-152.

Couse JF \& Korach KS 1999 Estrogen receptor null mice: what have we learned and where will they lead us? Endocrine Reviews 20 358-417.

Cunha GR, Young P, Hom YK, Cooke PS, Taylor JA \& Lubahn DB 1997 Elucidation of a role for stromal steroid hormone receptors in mammary gland growth and development using tissue recombinants. Journal of Mammary Gland Biology and Neoplasia 2 393-402.

Farr VC, Stelwagen K, Cate LR, Molenaar AJ, McFadden TB \& Davis SR 1996 An improved method for the routine biopsy of bovine mammary tissue. Journal of Dairy Science 79 543-549.

Feldman M, Ruan W, Tappin I, Wieczorek R \& Kleinberg DL 1999 The effect of $\mathrm{GH}$ on estrogen receptor expression in the rat mammary gland. Journal of Endocrinology 163 515-522.

Giguere V 1999 Orphan nuclear receptors: from gene to function. Endocrine Reviews 20 689-725.

Giguere V 2002 To ERR in the estrogen pathway. Trends in Endocrinology and Metabolism 13 220-225.

Giguere V, Yang N, Segui P \& Evans RM 1988 Identification of a new class of steroid hormone receptors. Nature 331 91-94.

Green P, Falls K \& Crooke S 1990 CRI-MAP documentation, version 2.4. Available at http://linkage.rockefeller.edu/soft/crimap/.

Greene GL, Gilna P, Waterfield M, Baker A, Hort Y \& Shine J 1986 Sequence and expression of human estrogen receptor complementary DNA. Science 231 1150-1154.

Haslam SZ \& Levely ML 1985 Estrogen responsiveness of normal mouse mammary cells in primary cell culture: association of mammary fibroblasts with estrogenic regulation of progesterone receptors. Endocrinology 116 1835-1844.

Haslam SZ \& Shyamala G 1979 Progesterone receptors in normal mammary glands of mice: characterization and relationship to development. Endocrinology 105 786-795.

Herrenkohl L 1974 Differential effects of progesterone on lactation and nursing behavior in late pregnant and postparturient rats. Physiology and Behavior 13 495-499.

Jensen EV \& Jacobsen HI 1962 Basic guides to the mechanism of estrogen action. Recent Progress in Hormone Research 18 387-414.

Kastner P, Krust A, Turcotte B, Stropp U, Tora L, Gronemeyer H \& Chambon P 1990 Two distinct estrogen-regulated promoters generate transcripts encoding the two functionally different human progesterone receptor forms A and B. EMBO Journal 9 1603-1614.

Kraus RJ, Ariazi EA, Farrell ML \& Mertz JE 2002 Estrogen-related receptor alpha 1 actively antagonizes estrogen receptor-regulated transcription in MCF-7 mammary cells. Journal of Biological Chemistry 277 24826-24834.

Krege JH, Hodgin JB, Couse JF, Enmark E, Warner M, Mahler JF, Sar M, Korach KS, Gustafsson JA \& Smithies O 1998 Generation and reproductive phenotypes of mice lacking estrogen receptor beta. PNAS 95 15677-15682.

Kuhn NJ 1969 Specificity of progesterone inhibition of lactogenesis. Journal of Endocrinology 44 615-616.

Kuiper GG, Enmark E, Pelto-Huikko M, Nilsson S \& Gustafsson JA 1996 Cloning of a novel receptor expressed in rat prostate and ovary. PNAS 93 5925-5930.

Liu YH, Yang NY \& Teng CT 1993 COUP-TF acts as a competitive repressor for estrogen receptor-mediated activation of the mouse lactoferrin gene. Molecular and Cellular Biology $\mathbf{1 3}$ 1836-1846.

Luo J, Sladek R, Carrier J, Bader JA, Richard D \& Giguere V 2003 Reduced fat mass in mice lacking orphan nuclear receptor estrogen-related receptor alpha. Molecular and Cellular Endocrinology 23 7947-7956.

Lydon JP, DeMayo FJ, Funk CR, Mani SK, Hughes AR, Montgomery CA Jr, Shyamala G, Conneely OM \& O'Malley BW 1995 Mice lacking progesterone receptor exhibit pleiotropic reproductive abnormalities. Genes and Development 9 2266-2278.

Lyons WR 1958 Hormonal synergism in mammary growth. Proceedings of the Royal Society B 149 303-325.

McDonnell DP \& Norris JD 2002 Connections and regulation of the human estrogen receptor. Science 296 1642-1644.

Mootha VK, Handschin C, Arlow D, Xie X, St Pierre J, Sihag S, Yang W, Altshuler D, Puigserver P, Patterson N, Willy PJ, Schulman IG, Heyman RA, Lander ES \& Spiegelman BM 2004 ERRalpha and GABPa/b specify PGC-1 alpha-dependent oxidative phosphorylation gene expression that is altered in diabetic muscle. PNAS 101 6570-6575.

Mueller SO, Clark JA, Myers PH \& Korach KS 2002 Mammary gland development in adult mice requires epithelial and stromal estrogen receptor alpha. Endocrinology 143 2357-2365.

Nandi S 1958 Endocrine control of mammary gland development and function in the $\mathrm{C}_{3} \mathrm{H} / \mathrm{He} \mathrm{Crgl}$ mouse. Journal of the National Cancer Institute 21 1039-1063.

Petersen DN, Tkalcevic GT, Koza-Taylor PH, Turi TG \& Brown TA 1998 Identification of estrogen receptor beta2, a functional variant of estrogen receptor beta expressed in normal rat tissues. Endocrinology 139 1082-1092.

Press MF \& Greene GL 1988 Localization of progesterone receptor with monoclonal antibodies to the human progestin receptor. Endocrinology 122 1165-1175.

Puigserver P \& Spiegelman BM 2003 Peroxisome proliferator-activated receptor-gamma coactivator 1 alpha (PGC-1 alpha): transcriptional coactivator and metabolic regulator. Endocrine Reviews 24 78-90.

Saji S, Sakaguchi H, Andersson S, Warner M \& Gustafsson J 2001 Quantitative analysis of estrogen receptor proteins in rat mammary gland. Endocrinology 142 3177-3186.

Saunders PT 1998 Oestrogen receptor beta (ER beta). Reviews of Reproduction 3 164-171.

Schams D, Kohlenberg S, Amselgruber W, Berisha B, Pfaffl MW \& Sinowatz F 2003 Expression and localisation of oestrogen and progesterone receptors in the bovine mammary gland during development, function and involution. Journal of Endocrinology 177 305-317.

Schreiber SN, Knutti D, Brogli K, Uhlmann T \& Kralli A 2003 The transcriptional coactivator PGC-1 regulates the expression and activity of the orphan nuclear receptor estrogen-related receptor alpha (ERRalpha). Journal of Biological Chemistry 278 9013-9018. 
Shamay A, Zeelon E, Ghez Z, Cohen N, Mackinlay AG \& Gertler A 1987 Inhibition of casein and fat synthesis and alpha lactalbumin secretion by progesterone in explants from bovine lactating mammary glands. Journal of Endocrinology 113 81-88.

Shigeta H, Zuo W, Yang N, DiAugustine R \& Teng CT 1997a The mouse estrogen receptor-related orphan receptor alpha 1: molecular cloning and estrogen responsiveness. Journal of Molecular Endocrinology 19 299-309.

Shigeta H, Zuo W, Yang N, DiAugustine R \& Teng CT 1997 b The mouse estrogen receptor-related orphan receptor alpha 1: molecular cloning and estrogen responsiveness. Journal of Molecular Endocrinology 19 299-309.

Shyamala G 1999 Progesterone signaling and mammary gland morphogenesis. Journal of Mammary Gland Biology and Neoplasia 4 89-104.

Shyamala G \& Ferenczy A 1982 The nonresponsiveness of lactating mammary gland to estradiol. Endocrinology 110 1249-1256.

Shyamala G, Schneider W \& Schott D 1990 Developmental regulation of murine mammary progesterone receptor gene expression. Endocrinology 126 2882-2889.

Shyamala G, Chou YC, Louie SG, Guzman RC, Smith GH \& Nandi S 2002 Cellular expression of estrogen and progesterone receptors in mammary glands: regulation by hormones, development and aging. Journal of Steroid Biochemistry and Molecular Biology 80 137-148.

Silberstein GB, Vanhorn K, Shyamala G \& Daniel CW 1994 Essential role of endogenous estrogen in directly stimulating mammary growth demonstrated by implants containing pure antiestrogens. Endocrinology 134 84-90.

Sladek R, Bader JA \& Giguere V 1997 The orphan nuclear receptor estrogen-related receptor alpha is a transcriptional regulator of the human medium-chain acyl coenzyme A dehydrogenase gene. Molecular and Cellular Endocrinology 17 5400-5409.

Smith JJ, Capuco AV \& Akers RM 1987 Quantification of progesterone binding in mammary tissue of pregnant ewes. Journal of Dairy Science 70 1178-1185.

Sonstegard TS, Capuco AV, White J, Van Tassell CP, Connor EE, Cho J, Sultana R, Shade L, Wray JE, Wells KD \& Quackenbush J 2002 Analysis of bovine mammary gland EST and functional annotation of the Bos taurus gene index. Mammalian Genome $\mathbf{1 3}$ 373-379.

Tremblay GB \& Giguere V 2002 Coregulators of estrogen receptor action. Critical Reviews in Eukaryotic Gene Expression 12 1-22.

Turkington RW \& Hill RL 1969 Lactose synthetase: progesterone inhibition of the induction of A-lactalbumin. Science $\mathbf{1 6 3}$ $1458-1460$
Vanacker JM, Pettersson K, Gustafsson JA \& Laudet V 1999 Transcriptional targets shared by estrogen receptor-related receptors (ERRs) and estrogen receptor (ER) alpha, but not by ER beta. EMBO Journal 18 4270-4279.

Vega RB \& Kelly DP 1997 A role for estrogen-related receptor alpha in the control of mitochondrial fatty acid beta-oxidation during brown adipocyte differentiation. Journal of Biological Chemistry 272 31693-31699.

Vega RB, Huss JM \& Kelly DP 2000 The coactivator PGC-1 cooperates with peroxisome proliferator-activated receptor alpha in transcriptional control of nuclear genes encoding mitochondrial fatty acid oxidation enzymes. Molecular and Cellular Endocrinology 20 $1868-1876$.

Wallace C 1953 Observations on mammary development in calves and lambs. Journal of Agricultural Science 43 413-421.

Womack JE, Dietz AB, Gallagher DS, Li L, Zhang N, Neibergs HL, Moll YD \& Ryan AM 1991 Assignment of 47 additional comparative anchor loci to the bovine syteny map. Cytogenetics and Cell Genetics $\mathbf{5 8} 2132$.

Woodward TL, Xie JW \& Haslam SZ 1998 The role of mammary stroma in modulating the proliferative response to ovarian hormones in the normal mammary gland. Journal of Mammary Gland Biology and Neoplasia 3 117-131.

Yang N, Shigeta H, Shi H \& Teng CT 1996 Estrogen-related receptor, hERR1, modulates estrogen receptor-mediated response of human lactoferrin gene promoter. Journal of Biological Chemistry 271 5795-5804.

Yee D \& Lee AV 2000 Crosstalk between the insulin-like growth factors and estrogens in breast cancer. Journal of Mammary Gland Biology and Neoplasia 5 107-115.

Zhang Z \& Teng CT 2000 Estrogen receptor-related receptor alpha 1 interacts with coactivator and constitutively activates the estrogen response elements of the human lactoferrin gene. Journal of Biological Chemistry 275 20837-20846.

Zhang Z \& Teng CT 2001 Estrogen receptor alpha and estrogen receptor-related receptor alpha1 compete for binding and coactivator. Molecular and Cellular Endocrinology 172 223-233.

Received 3 January 2005

Accepted 24 March 2005

Made available online as an

Accepted Preprint 6 April 2005 